\title{
Fungating metastatic breast cancer, a challenging case report of bleeding control and palliative wound care
}

\author{
Haynes Addison ${ }^{1}$, Simman Richard ${ }^{2}$ \\ ${ }^{1}$ Grandview Medical Center, Dayton Ohio, Clinical Instructor, CORE Group IV faculty, Ohio University Heritage College of Osteopathic \\ Medicine \\ ${ }^{2}$ Clinical Associate Professor in Plastic and Reconstructive Surgery, Associate Research Professor, Department of Pharmacology and \\ Toxicology at Wright State University Boonshoft School of Medicine, Dayton, Ohio
}

\author{
Email address: \\ richardsimman@hotmail.com (R. Simman)
}

\section{To cite this article:}

Haynes Addison, Simman Richard. Fungating Metastatic Breast Cancer, a Challenging Case Report of Bleeding Control and Palliative Wound Care. European Journal of Preventive Medicine. Vol. 2, No. 3, 2014, pp. 29-32. doi: 10.11648/j.ejpm.20140203.11

\begin{abstract}
This case will discuss the palliative care in an advanced metastatic and fungating breast cancer. As sometimes happens, patients elect to go with different means of treatment and not the mastectomy with lymph node dissection, radiation, and chemotherapy that is the standard of care. Even though the patient elected not to attempt the full surgery, there are still surgical options that could have helped her quality of life and are important to consider. Wound care can be curative for many different wounds but can also greatly improve the quality of life that is present. Wounds leave the body exposed to secondary infections and can produce foul odor which is not conducive to patient or family comfort and happiness. It can be used in conjunction with many different treatments and should not be forgotten in the treatment of all patients. In this case we also discussed a variety of methods for bleeding control of this cancerous mass.
\end{abstract}

Keywords: Fungating Breast Cancer, Palliative Wound Care, Bleeding Control

\section{Introduction}

Breast cancer has recently been in the media more with talks about the treatment and screening options available to women. The National Cancer Institute's Surveillance Epidemiology and End Results database collected data from 1992 to 2001; it showed 7 different types of breast cancer that were responsible for more than 95 percent of the cases reports. Inflammatory breast cancer (IBC) accounted for only 0.5 to 2 percent of the invasive breast cancers diagnosed. ${ }^{1,2,5}$

IBC often presents at an earlier age and is easily mistaken with several other conditions that can lead to delays in diagnosis and treatment. This delay in diagnosis, means that nearly one-third of women diagnosed with IBC have distant metastases at time of diagnosis. 2, 7, 16

This case will discuss care well after diagnosis. As sometimes happens, patients elect to go with different means of treatment and not the mastectomy with lymph node dissection, radiation, and chemotherapy that is the standard of care. ${ }^{3,4,8,9,10,11,12,13}$ Even though the patient elected not to attempt the full surgery, there are still surgical options that could have helped her quality of life and are important to consider. Wound care can be curative for many different wounds but can also greatly improve the quality of life that is present. Wounds leave the body exposed to secondary infections and can produce a foul odor which is not conducive to patient or family comfort and happiness. It can be used in conjunction with many different treatments and should not be forgotten in the treatment of all patients. 15,16

\section{Case Report}

The patient is a 55 year old female who presented to a long term acute care facility (LTAC) for ventilator wean and care of her fungating right breast mass (Figure 1). Patient had been diagnosed with an invasive breast cancer earlier in the year that had been rapidly spreading. She and her family elected not to go with the standard of care and instead chose alternative medicine that included several different infusions. The mass had been bleeding constantly at home and eventually required IV infusion of iron in an effort to keep her hemoglobin at an acceptable level. During an infusion of iron at an outpatient center, patient suffered cardiac arrest with pulseless electrical activity. 
Patient had spontaneous return of circulation after being intubated and given a dose of epinephrine. She was transferred to the nearest hospital where she was placed on a ventilator. Patient had a tracheotomy done one week later as she remained on the ventilator.



Figure 1. Fungating right breast mass

During her stay in the hospital, the mass grew multiple organisms including Klebsiella, Enterococcus, MSSA, enterobacter, pseudomonas, and anaerobes. She was given linezolid and meropenem initially but was changed to piperacillin/tazobactam, ciprofloxacin, and fluconazole based on the culture and the sensitivities. Surgery was consulted about possible debulking of the mass but this was not done. Patient had expressed wishes not to have it done as it was a high-risk surgery and would not be curative.

Patient was admitted to the LTAC with a white blood cell count of 36,000 and hemoglobin of $8.4 \mathrm{~g} / \mathrm{dL}$. Patient was on 40 percent $\mathrm{FiO} 2$ just to keep her oxygen saturation above 92 percent. A large mass was present on the right breast that was purulent and had a foul odor.

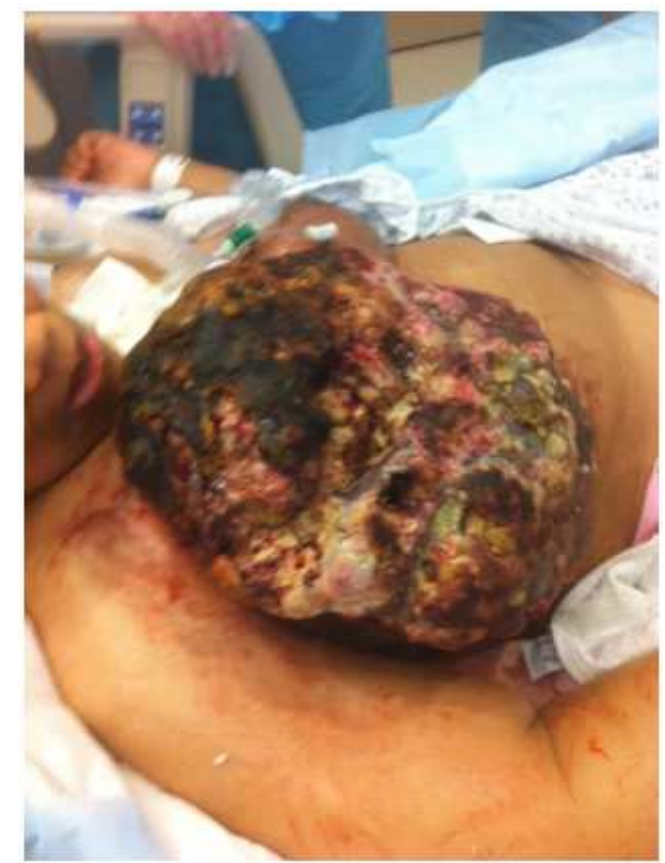

Figure 2. Right breast mass with tissue necrosis and clotted blood
The breast cancer continued to grow in size and bleed on a regular basis during her stay at the LTAC (Figure 2). Family refused to allow a debulking procedure to reduce the weight on the patient's chest or to help with the bleeding. She received different courses of antibiotics for the next two months for her recurrent septicemia. Her WBC did reach a maximum of 52,000. Eventually the infectious disease team concluded that additional antibiotic use would not be beneficial to the patient.

Many different hemostatic agents were used in an attempt to control the bleeding and charcoal based dressings were applied to help with the foul odor. It was very difficult to control the bleeding. Many topical hemostatic agents were used to control her bleeding including Thrombin, Surgicel, silver nitrate and others. The dressings were soaked with normal saline at the time of dressing changes to minimize that adherence which oftens leads to bleeding at the time of removal of dry dressings. In spite of these measures, recurrent bleeding from the mass, lead to the patient receiving blood transfusions and IV iron supplementation. Wound care continued to be very challenging. Topical antimicrobials were used in an attempt to keep the bioburden down. The patient showed no signs of upper level brain function during her time at the LTAC, likely secondary to an anoxic injury sustained during her cardiac arrest. After almost 3 months in the LTAC, the patient's family decided to stop IV fluids, blood draws, and blood transfusions. The patient's code status had already been changed to do not resuscitate. The patient was kept comfortable and expired several days later.

\section{Discussion}

The 2010 American Joint Committee on Cancer and the International Union for Cancer Controls TNM breast cancer staging system defines IBC as a clinical-pathologic entity that is characterized by diffuse erythema and edema. The diagnosis is based upon clinical presentation. An international expert panel suggested that IBC must include:

1) Rapid onset of breast erythema, edema or peau $\mathrm{d}$ /orange, with or without an underlying palpable mass

2) Duration of history no more then 6 months

3) Erythema that occupies at least one-third of the breast

4) Pathologic confirmation of invasive carcinoma. ${ }^{19}$

IBC must be differentiated from other diseases to better aid in treatment. It is not a true inflammatory process unlike mastitis and breast abscesses. Ductal ectasis is usually localized and does not spread like IBC. A full thickness skin biopsy should be obtained which would show dermal lymphatic invasion by tumor cells. At least 2 separate punch biopsies should be obtained. Ultrasound of suspicious lymph nodes with fine needle aspiration should be obtained quickly as IBC progresses rapidly to metastatic disease. Bone, liver, and pulmonary imaging studies can be obtained, as these are the most likely sites of distant metastases. 
Neoadjuvant chemotherapy should be started as soon as possible with tumor debulking to take place shortly thereafter. $^{14}$ The only method of definitive surgery suggested by expert panel is modified radical mastectomy. Skin sparing mastectomy is contraindicated for IBC. It is suggested that surgery should only be attempted is macroscopically complete resection can be accomplished. Patient's with metastatic disease have a poor prognosis and are often not a candidate for surgery. ${ }^{20,21,22}$

Palliative surgery can be very beneficial in patient's care. Debulking surgery should be considered in patients whose mass is causing secondary problems. A large growing mass that often bleeds can lead to inadequate nutrition and a site of potential infection. The size of a tumor can also impede a patients breathing. Surgery in these patients is not done as a curative measure, but rather to improve a patient's quality of life. The reduction in complications can also increase a patient's life span.

As we consider surgical options, timing is important. Referral needs to be made early enough that the patient can tolerate the surgery. ${ }^{1,3,4,6,8,9,15,17}$ Patients with large tumors that cannot be entirely removed are often not considered for surgery because it is not curative. ${ }^{18}$ The size of this tumor made it very hard for the patient to breath when lying on her back. It slowly got worse as the tumor enlarged in size greatly increasing patient's work of breathing. An early debulking procedure could have greatly reduced the weight the patient was working against to breath. ${ }^{15,17}$

The patient's growing tumor also interfered with her ability to maintain good nutritional intake. The patient quickly depleted her vitamins, nutrients, and essential minerals. This lack of nutrition lead to problems later in the patient's life as she began to bleed. She was unable to replenish her coagulation cascade and platelets to clot off the bleeding. Her tumor was very vascular by the time would care was consulted to see the patient and adequate hemostasis was unable to be maintained. Early intervention could have reduced the caloric burden on the patient and helped her nutritional status.

The vascularity of the tumor grew exponentially as it expanded in size. Again early intervention could have stopped the blood flow that was supplying the tumor. This could have slowed the rate of growth, allowing the patient to spend more quality time with family and friends. Staying ahead of the growing and increasing complex vascular network is very important. It is easier when early consultation is obtained from surgery and wound care team.

Surgery can be used to help improve the patient's quality of life and make their activities of daily living easier. It can also lengthen the amount of time that they can spend with their families and loved ones, but it must be done at the appropriate time in a patient's course of treatment. Wound care and surgery should be consulted early in IBC, though it is not curative. Having a wound care specialist on board can significantly improve patient's quality of life.

\section{References}

[1] Chia SK, Speers CH, D'yachkova Y, Kang A, Malfair-Taylor S, Barnett J, Coldman A, Gelmon KA, O'reilly SE, Olivotto IA; The impact of new chemotherapeutic and hormone agents on survival in a population-based cohort of women with metastatic breast cancer. Cancer. 2005, pp. 104(8): 1742 .

[2] Cristofanilli M, Buzdar AU, Hortobágyi GN; Update on the management of inflammatory breast cancer. Oncologist. 2003, pp. 8(2):141.

[3] Gennari A, Conte P, Rosso R, Orlandini C, Bruzzi P: Survival of metastatic breast carcinoma patients over a 20 year period: a retrospective analysis based on individual patient data from six consecutive studies. Cancer. 2005, pp. 104(8):1742.

[4] Dafni U, Grimani I, Xyrafas A, Eleftheraki AG, Fountzilas G: Fifteen-year trends in metastatic breast cancer survival in Greece. Breast Cancer Res Treat. 2010, pp. 119(3):621.

[5] Li CI, Uribe DJ, Daling JR: Clinical characteristics of different histologic types of breast cancer. $\mathrm{Br} J$ Cancer. 2005, pp. 93(9):1046.

[6] Dawood S, Merajver SD, Viens P, Vermeulen PB, Swain SM, Buchholz TA, Dirix LY, Levine PH, Lucci A, Krishnamurthy S, Robertson FM, Woodward WA, Yang WT, Ueno NT, Cristofanilli M: International expert panel on inflammatory breast cancer: consensus statement for standardized diagnosis and treatment. Ann Oncol. 2011, pp. 22(3):515.

[7] Kleer CG, van Golen KL, Merajver SD: Molecular biology of breast cancer metastasis. Inflammatory breast cancer: clinical syndrome and molecular determinants. Breast Cancer Res. 2000, pp. 2(6):423.

[8] Dawood S, Merajver SD, Viens P, Vermeulen PB, Swain SM, Buchholz TA, Dirix LY, Levine PH, Lucci A, Krishnamurthy S, Robertson FM, Woodward WA, Yang WT, Ueno NT, Cristofanilli M: International expert panel on inflammatory breast cancer: consensus statement for standardized diagnosis and treatment. Ann Oncol. 2011, pp. 22(3):515.

[9] Lyman GH, Giuliano AE, Somerfield MR, Benson AB 3rd, Bodurka DC, Burstein HJ, Cochran AJ, Cody HS 3rd, Edge SB, Galper S, Hayman JA, Kim TY, Perkins CL, Podoloff DA, Sivasubramaniam VH, Turner RR, Wahl R, Weaver DL, Wolff AC, Winer EP, American Society of Clinical Oncology: American Society of Clinical Oncology guideline recommendations for sentinel lymph node biopsy in earlystage breast cancer. J Clin Oncol. 2005, pp. 23(30):7703.

[10] Perez CA, Fields JN, Fracasso PM, Philpott G, Soares RL Jr, Taylor ME, Lockett MA, Rush C: Management of locally advanced carcinoma of the breast. II. Inflammatory carcinoma. Cancer. 1994, pp. 74(1 Suppl):466

[11] Yang, CH, Cristofanilli, M: Systemic treatments for inflammatory breast cancer. Breast Dis 2005-2006, pp. 22:55.

[12] Thoms WW Jr, McNeese MD, Fletcher GH, Buzdar AU, Singletary SE, Oswald MJ: Multimodal treatment for inflammatory breast cancer. Int J Radiat Oncol Biol Phys. 1989, pp. 17(4):739. 
[13] Harris EE, Schultz D, Bertsch H, Fox K, Glick J, Solin LJ: Ten-year outcome after combined modality therapy for inflammatory breast cancer. Int J Radiat Oncol Biol Phys. 2003, pp. 55(5):1200.

[14] Hennessy BT, Gonzalez-Angulo AM, Hortobagyi GN, Cristofanilli M, Kau SW, Broglio K, Fornage B, Singletary SE, Sahin A, Buzdar AU, Valero V. Disease-free and overall survival after pathologic complete disease remission of cytologically proven inflammatory breast carcinoma axillary lymph node metastases after primary systemic chemotherapy. Cancer. 2006, pp. 106(5):1000.

[15] De Boer RH, Allum WH, Ebbs SR, Gui GP, Johnston SR, Sacks NP, Walsh G, Ashley S, Smith IE: Multimodality therapy in inflammatory breast cancer: is there a place for surgery? Ann Oncol. 2000, pp. 11(9):1147.

[16] Brun B, Otmezguine Y, Feuilhade F, Julien M, Lebourgeois JP, Calitchi E, Roucayrol AM, Ganem G, Huart J, Pierquin B Treatment of inflammatory breast cancer with combination chemotherapy and mastectomy versus breast conservation. Cancer. 1988, pp. 61(6):1096.

[17] Bristol, IJ, Buchholz, TA: Inflammatory breast cancer: current concepts in local management. Breast Dis 20052006, pp. 22:75.
[18] Curcio LD, Rupp E, Williams WL, Chu DZ, Clarke K, Odom-Maryon T, Ellenhorn JD, Somlo G, Wagman LD: Beyond palliative mastectomy in inflammatory breast cancer--a reassessment of margin status. Ann Surg Oncol. 1999, pp. 6(3):249.

[19] American Joint Committee on Cancer Staging Manual, 7th, Edge SB, Byrd DR, Compton CC, et al (Eds), Springer, New York 2010.

[20] Dawood S, Merajver SD, Viens P, et al. International expert panel on inflammatory breast cancer: consensus statement for standardized diagnosis and treatment. Ann Oncol 2011, pp. 22:515.

[21] Tai P, Yu E, Shiels R, et al. Short- and long-term causespecific survival of patients with inflammatory breast cancer. BMC Cancer 2005, pp. 5:137.

[22] Hance KW, Anderson WF, Devesa SS, et al. Trends in inflammatory breast carcinoma incidence and survival: the surveillance, epidemiology, and end results program at the National Cancer Institute. J Natl Cancer Inst 2005, pp. 97:966. 